\title{
The plight of female agricultural wageworkers in Morocco during the COVID-19 pandemic
}

\author{
Lisa Bossenbroek ${ }^{1,2, *}$ and Hind Ftouhi ${ }^{2,3}$ \\ ${ }^{1}$ IES Landau, Institute for Environmental Sciences, University of Koblenz-Landau, Landau, Germany \\ ${ }^{2}$ Centre de Recherches et d'Études sur les Sociétés Contemporaines (CRESC), Rabat, Morocco \\ 3 Institut Agronomique et Vétérinaire Hassan II, Rabat, Morocco
}

\begin{abstract}
While vaccination campaigns against COVID-19 were launched worldwide, a drama has been unfolding in the Moroccan countryside. It has been marked, over the last couple of decades, by rapid agrarian transformation, manifestations of which have included expanding irrigation frontiers and the increasing growth of high-value crops. These dynamics rely strongly on female agricultural wageworkers. Although they earn low wages, their income is crucial and is used to care for loved ones by paying for school fees, rent, electricity, and medicines. These workers, therefore, cannot afford to quit their jobs. However, most female wageworkers in Morocco are employed without a contract or social security cover. While working in an informal environment and living already in a precarious situation, little is known about how the pandemic has affected them. In this article, we seek to supply some of this information by drawing on the authors' commitment over almost a decade of covering female wage-workers' experiences in different agricultural regions in Morocco. Additionally, since March 2020, we have conducted 30 phone interviews with female laborers and farmers in the Saiss and in the coastal area of the Gharb and Loukkos. Using the pandemic as a focus, our results illustrate the inherent contradictions upon which Morocco's agricultural boom has been founded. Although many female laborers are de facto heads of household or contribute in fundamental ways to the household income, they continue to be considered as secondary earners or as housewives, leading to low structural wages. Moreover, these women assume the prime responsibility for all domestic tasks, which are not economically recognized or valued. Consequently, they face new challenges in addition to their already precarious situations. Reduced work opportunities and limited state support have led to financial and psychological hardship which jeopardize their own and their family's survival.
\end{abstract}

Keywords: COVID-19 / Morocco / agrarian change / female agricultural wageworkers / social reproduction

Résumé - Le sort des ouvrières agricoles au Maroc à l'époque de la pandémie de Covid-19. Alors que des campagnes de vaccination contre le Covid-19 ont été lancées dans le monde entier, un drame silencieux s'est déroulé dans les campagnes marocaines. Au cours des deux dernières décennies, ces campagnes ont connu des transformations agraires rapides, liées, entre autres, à l'extension de l'irrigation et à l'adoption de cultures à haute valeur ajoutée. Cette dynamique dépend fortement de la mobilisation d'une main-d'œuvre agricole féminine. Le revenu des ouvrières leur est indispensable pour prendre soin de leurs proches, payer les frais de scolarité, les médicaments, le loyer et les factures. Cependant, la plupart des ouvrières travaillent sans contrat ni couverture sociale. Alors qu'elles vivent déjà dans une situation précaire, on sait peu de choses sur la manière dont la pandémie les a affectées. Dans cet article, nous cherchons à combler partiellement cette lacune. Pour ce faire, nous nous appuyons sur notre engagement de près d'une décennie auprès des ouvrières agricoles, et sur des entretiens téléphoniques réalisés avec des ouvrières et des agriculteurs du Saïss et de la zone côtière du Gharb et du Loukkos depuis mars 2020. En mobilisant la pandémie comme une loupe, nos résultats illustrent les contradictions sur lesquelles repose le boom agricole au Maroc. Bien que de nombreuses ouvrières soient de facto chefs de famille ou contribuent de manière essentielle aux revenus du ménage, elles continuent d'être considérées comme des sources de revenus secondaires ou des femmes au foyer, d'où des salaires structurellement bas. En outre, ces femmes sont

*Corresponding author: bossenbroek@uni-landau.de 
responsables de toutes les tâches domestiques, alors que celles-ci ne sont pas reconnues ou valorisées économiquement. Ainsi, alors qu'elles étaient déjà dans une situation précaire, pendant la pandémie les femmes ont dû affronter des difficultés financières et psychologiques, liées à la réduction des opportunités de travail et au soutien limité de l'État, qui ont mis en péril leur survie et celle de leur famille.

Mots clés : Covid-19 / Maroc / ouvrières agricoles / changements agraires / reproduction sociale

\section{Introduction}

From mid-March 2020 onwards, the Moroccan government has instituted a lockdown to prevent the spread of the COVID-19 pandemic, resulting in restrictions on mobility, a ban on gatherings, and, when possible, working from home. The two authors of this paper had the privilege of working from home while eating nationally-produced and tasty fruit and vegetables. We subsisted thanks to the hard work of some female agricultural wageworkers who continued to work during the lockdown.

Various scholars have discussed how Morocco embarked on a path of agricultural development that strongly relies on a female workforce (Bossenbroek, 2019; Théroux-Séguin, 2016). Farmers are keen to hire women because of their cheap labor cost and their presumed docility as well as their reputed "care" in handling fruits and vegetables. However, most female wageworkers are employed with neither a contract nor social security cover and often work through informal arrangements. Consequently, they remain "invisible" in official statistics. Despite these poor working conditions, they have to work to guarantee the survival and well-being of themselves and their loved ones and cannot afford to quit their jobs. While living already in a precarious situation, which makes them more vulnerable to shocks such as the COVID-19 pandemic, little is known about how the pandemic has affected them. What happens to these women and their families when work opportunities drop? What happens if they cannot travel to their work anymore due to the lockdown related restrictions and lose their income?

To help addressing this gap in knowledge, we draw on various scholars who have analyzed particular processes of profit-making from a feminist perspective. For example, Maria Mies (1982) illustrated how the 1980s capitalist expansion in India relied on the hard (invisible) work of rural women. They were "invisible" because they were considered housewives and, thus, their work was considered "housework" or as reproductive activities, which are not economically considered. This allowed the lace industry in India to successfully expand in that decade.

An important feminist endeavor has been to acknowledge such reproductive activities. As much of this is unpaid and carried out in the family's intimate domain, classical economics have not considered such activities to be valuable and to contribute to the economy. Nevertheless, to justly acknowledge these responsibilities, feminist researchers have developed the concept of social reproduction, which refers to the activities and attitudes, behaviors and emotions, responsibilities and relationships that are directly involved in the maintenance of life on a daily basis and across generations (Laslett and Brenner, 1989, p. 382). Thus, the concept of social reproduction allows us to go beyond the "visible" (in our case, a privileged minority of agricultural workers who have contracts and health care insurance) to interrogate the complex network of social processes and human relations that produces the conditions of existence of a particular entity (Bhattacharya, 2017, p. 2).

Nancy Fraser (2017), in the same vein as Mies, goes beyond acknowledging the importance of reproductive work to critically question the role of this type of work in promoting growth and unlimited profit-making. She argues that, although societies cannot long endure when they systematically undermine social reproduction, new profit-making forms do just that. According to the author, the process of unlimited accumulation rests on a profound contradiction: on the one hand, social reproduction is a condition for capital accumulation; on the other hand, unlimited accumulation tends to destabilize the very processes of social reproduction on which it relies.

Seen through a social reproductive lens, the plight of female agricultural wageworkers during COVID-19 reveals (1) how, although many female laborers are de facto heads of household or contribute in fundamental ways to the household income, they continue to be considered as secondary earners or as housewives; and (2) although they are seen as being responsible for everything that is "reproduction", these activities are systematically undervalued and economically not recognized. As we will see further on in the paper, these two contradictions, allowing the agricultural sector to flourish, have led during the COVID-19 pandemic to the "invisible" crisis of reproduction: female workers and their families struggled to survive and make ends meet.

\section{Study area}

The study was conducted in the Saiss and the coastal area of the Gharb and Loukkos in Morocco. Agriculture is the main activity in both regions. Their agricultural sectors are characterized by a juxtaposition of different farming modes (large export-oriented farms; entrepreneurial and peasant farms; sharecroppers) and agricultural transformation industries. The Saiss is known for its variety of vegetables; recently, different fruits have also been grown, such as grapes, peaches, and nectarines. The Gharb and Loukkos area is renowned for its berry production. Over the last couple of decades, both areas have been marked by rapid agrarian transformation manifested in the use of new technologies (like deep tube-wells, drip irrigation, and water basins), new land tenure arrangements that favor intensive farming practices, the expansion of irrigated land, and a shift from food crops to high value crops. For example, in the Loukkos-Gharb region, the area cultivated with strawberries grew from 100 hectares in the early 1990 s to 3,600 ha in 2016-2017 (Harbouze et al., 2019). The agricultural sector growth relies strongly on a female 
workforce (Bossenbroek, 2019; Théroux-Séguin, 2016). Only a privileged minority of laborers have work contracts; the vast majority - especially those employed by entrepreneurs, and peasant farmers and laborers who find their work through the moquefs (informal labor markets where workers try to find a job for the day) - do not have contracts and social security.

\section{Methods}

This research relies on the authors' commitment over almost a decade of covering female wage-workers' experiences in different agricultural regions in Morocco (Bossenbroek, 2016, 2019). When the COVID-19 pandemic started, we began contacting workers and farmers we knew through our earlier fieldwork activities $(2013,2016)$ and with whom we have since kept in touch. We then used the snowball sampling method to reach other workers. When asking the women we interviewed to put us in touch with other laborers, we only said that we wanted to talk to other workers without mentioning any other socio-economic selection criteria. Based on this method, we spoke to female workers of different ages with different marital statuses (single, divorced, married, widowed). Notwithstanding, what these women have in common is that their income is essential to guaranteeing their survival and that of their family members. In the first round of interviews, we conducted 18 semistructured phone interviews with five farmers and 13 female laborers. Questions to the farmers focused on how the pandemic and subsequently lockdown had affected laborers' recruitment, what health measures they took, and how they generally coped with the situation. Questions to the female workers focused on how the pandemic and lockdown had affected their work, if they had received any support, and how they coped. Based on these insights, we conducted 12 structured phone questionnaires with female laborers, which allowed us to gain a more in-depth understanding of the impact of the pandemic on their lives.

\section{Responsibilities to sustain oneself and loved ones}

Although men continue to be socially considered in the Moroccan countryside as the primary financial providers for households, all the women we interviewed stated that they are either the primary financial providers or share this responsibility with other family members. For example, Nora (the names throughout this paper have been changed to pseudonyms), aged 39, explained: "I am single, I cannot leave my mother alone, she is sick. I am the one who is in charge of her." The testimony of Fatna, who is 45 years old and has three children, also revealed how, although her husband works, she is responsible for maintaining her family: "He [her husband] works from time to time as an agricultural laborer to buy cigarettes. [...] I am the one who works and provides for the needs of the house." As such, even in families where spouses work, women's incomes remain essential due to the lack of control they have over their husbands' income, and its irregularity. Wages are used to provide food, medicines, and pay for bills and children's education. In addition, the women interviewed are responsible for cooking, washing clothes, and looking after their children, parents, or siblings, and carry the psychological burden and the constant worry of fulfilling their caring responsibilities.

\section{The impacts of the pandemic on female wageworkers}

The lockdown due to the COVID-19 pandemic imposed towards the end of March 2020, had drastic consequences for female wageworkers. Usually, during this time of the year, the demand for labor is at its peak. Laborers who rely on casual work gather in the moquefs. Since the labor demand is high at this time of the year, laborers can get relatively high wages, which are saved for off-peak periods. In 2020, however, lockdown measures disrupted the organization of agricultural work.

\subsection{Structural low wages and new challenges to finding work}

For a full day of work, women receive around 70 dirhams $( \pm 6.5 €)$. However, most of the women interviewed agreed that, although their wages did not drop during the pandemic, they are low: "The work is exhausting. A salary of $70 \mathrm{Dh}$ is meager, but in the end, it is better than nothing. That's where the problem lies." During interviews conducted in 2013 and 2016, managers and farmers justified low wages paid to women on the basis that women wages are "just pocket money" or "secondary incomes". Joekes (1985) observed similar attitudes towards female workers in Morocco's textile industry. Employers justified low wages because women "work for lipstick": they do not need to support a family but work only to provide a little extra money for small personal luxuries. Indeed, not recognizing women as primary income providers but, instead, as housewives sustained by their husbands, allows employers to pay them low wages.

While already earning low incomes, the women explained that their work opportunities dropped: "Before Corona [sic.], we used to work every day. Now, we only work three days per week, and sometimes we only work one day a week. Because of Corona, there isn't any work." Several reasons were given for this decline.

Due to mobility restrictions, laborers had difficulties in finding work or reaching the farms and agribusinesses where work is available. A travel permit, delivered by local authorities, is required to move around. Nevertheless, since most of the workers we interviewed do not have contracts, it is difficult for them to obtain such a permit. This compromised their chances of finding work, especially on farms located in communities far from their homes. This is illustrated by Nadia, widowed and aged 40, in charge of her four children: "The other day, they offered me work in the area. [...] I asked for a permit allowing me to travel for work. However, the Moqadem [local representative of the Ministry of the Interior] refused to give it to me."

Moreover, because of the ban on gatherings, moquefs were prohibited. Female workers who tried to gather in the moquefs explained that they would be chased away by the local authorities, or would be brought to the police station. This is explained by Hasna, single and aged 40: "They took us several 
times to the police station; they told us: 'Gatherings are forbidden, do not get in crowded vehicles, you must have a travel permit, and wearing a mask is mandatory...." Zineb, aged 39, divorced and in charge of her son, also explained how "...we arrived at the moquef at 4:00 in the morning. At 5:30, the authorities arrived and asked us to return to our houses. So, we went home. I felt bad and had tears in my eyes."

In addition, some farmers preferred switching to family labor, which further dropped the demand for labor. They feared getting infected; since schools were closed because of the lockdown measures, youngsters and children stayed home and were able to help on the farm. Other farmers could not afford to recruit external laborers due to financial problems.

As work opportunities dropped, women had to seek other income sources. All hoped to benefit from the government's support schemes, but few did, as illustrated below.

\subsection{Difficulties in benefitting from governmental support programs}

The Moroccan government launched the Tadamon ("solidarity" in Arabic) program to provide financial support to various vulnerable groups during the COVID-19 pandemic. However, of all the women interviewed, only two had benefited from it. Three other women claimed that other family members had received it. Fatna, aged 49, married and the mother of two children, explained that even if "... I am the one who provides for the house and my daughter..." her husband is considered the de facto head of the household. He received the government aid, preventing her from benefitting directly from it. The remaining women interviewed claimed that they did not receive government support. Some of them ignored the reason behind the rejection of their application. Others explained that they struggled to complete the requested forms, attributing this to their illiteracy. Souad, aged 48, widowed with one child, mentioned: "An illiterate person is like a person who walks in the darkness." Her three requests to receive support were rejected.

On the other hand, most women, or one of their family members, benefited from food baskets that municipalities or local NGOs handed out to vulnerable families during Ramadan or when villages were put under lockdown. Additionally, two widowed women received a monthly pension of $350 \mathrm{Dh}$ $( \pm 32 €)$. However, in general, both forms of support were found to be insufficient. Consequently, the women interviewed felt a growing sense of frustration and injustice. The experience of Aziza, who was around 35 and divorced, illustrates this well. She applied for the COVID-19 support program but had to ask someone's help because of her illiteracy. However, according to her, "The guy who helped me made a mistake, and my demand was rejected." She later told us how "I did not work during the lockdown. [...] I have not received any support because the form was wrongly filled in. I have suffered psychologically because financially well-off people have received help... and $I$, who needs it, received nothing. I felt injustice, I closed my door, and I did not go out anymore." In a context where state social provision is weak, the responsibility to financially support and maintain loved ones and oneself lies as a heavy burden on the shoulders of the female wageworkers interviewed.

\subsection{Financial and psychological problems}

Financial problems became an endemic concern in female workers' daily lives, with important repercussions for their reproductive responsibilities. At the beginning of the lockdown, the interviewed women explained how they would live from their savings and how "...we do with what we have..." and "...manage to make ends meet". However, as Khadija explains "[...] with the children's expenses and a daily remunerated job, you cannot save much money!".

As the weeks without employment passed, savings quickly dried up and different cuts in basic provisions were required. Nadia explained: "I no longer take medication for my heart disease ... I finished the last box before Ramadan, and I no longer bought it. [...] I stopped it for two reasons: I am afraid to go to the doctor, and I do not have the money to buy the medicines." Others could not provide for their children's or siblings' educational essentials in studying online, such as tablets, phones, or internet recharges, or could not afford tuition fees. Nadia explained: "My oldest daughter was eager to succeed in her school year. She asked me to buy her a phone so that she could study online. I have an old Nokia phone. I could not figure out what to do; what could I do? I told her, I cannot do anything for you; it's your destiny." Other women compromised on their meals, cutting out food items as Fatna testified: "We have to reduce expenses when we go to the market... 200-250 dirhams will not buy you anything... You feel helpless, and you end up buying $1 / 2 \mathrm{~kg}$ of everything, and you go home."

In such a context, the majority of the women interviewed expressed anxiety about their ability to sustain their children, parents, siblings, and themselves. These responsibilities weighed heavy on their shoulders, as Hasna affirmed: "I am tired of hard work. I am tired of the crisis [...] I want to take a rest from everything. I play the role of the woman and the man. I worry about rent, electricity, and water bills, I think about my parents and brothers and that I have to provide for them." The following experience of Souad adds an essential supplement to this; she explained how she felt "suffocated ... I have no one to lean on, there is no one who thinks of me. I have to work to provide for myself. I have to do everything myself. I feel lonely...". Amid the pandemic, an "invisible" crisis appears to be emerging where these women seem to literally be on their own.

\section{Survival strategies deployed}

In light of financial constraints, limited government support, and a heavy burden to maintain loved ones, women tried to resume their work activities or find other ways to enable their families and themselves to survive. In what follows, we elaborate on the different survival strategies deployed by female wageworkers to navigate these challenges in a time of pandemic.

\subsection{Resuming work and "working secretly so that the authorities do not see us"}

Facing an increasingly difficult financial situation, all laborers interviewed were forced to resume their work and to 
try and circumvent the lockdown restrictions. For example, despite the ban on gatherings, women tried to go to the moquef. To avoid roadblocks, they started to gather around 4:00 a.m. to avoid being seen and chased away by the authorities: "I go from time to time to the moquef... The authorities chase us away. We work secretly so that they don't see us." Others started to gather in other (strategic) spots in small agricultural towns to avoid being chased away, as illustrated by Hasna: "The authorities assigned another spot for the moquef. It's far away, and you have to walk more than half an hour to get there. There is a risk that someone will attack you because we usually go to the moquef at 4:00 and it is always dark at that time. So, we picked another gathering spot, close to the exit of the city."

\subsection{Mobilization of one's professional or neighborhood network}

Rather than finding work through the moquef, other interviewees preferred to mobilize their professional or neighborhood network established over many years of farming work. In this context, farmers contacted laborers directly: "He [the farmer] sends his son to tell us to come and work. On other occasions, the neighbor, who knows that we go to the moquef, offers work on his farm." Farmers collect the laborers from their homes and bring them to the farm. Others again preferred to work on small farms in their own and neighboring localities which are located within walking distance. They did so to avoid collective means of transport — which are generally used to bring laborers to farms located further away - to avoid being stopped by the police.

\subsection{Taking hygienic measures}

Women forced to go back to work faced a greater risk of being infected with the coronavirus. While farmers or managers would sometimes take hygienic measures, this was not always the case. Half of the women interviewed explained that farmers/managers provided masks, disinfectant gel and followed the social distancing protocol. The rest of the interviewees explained that none of the hygienic measures were respected on the farm where they work. According to Nadia: "Farmers do not worry about health measures. They are not interested in us. We come and work the agreed hours and go home. What matters to them is that agricultural work is done well." Either way, the women interviewed always took measures to protect themselves. For example, they would eat their meals alone during lunch breaks, away from others. They also brought their own masks, soap, and/or disinfectant gel, as confirmed by Rahma: "We disinfect our hands. I always take lavender soap and a little bit of bleach with me. I wipe my hands with my towel, and then I eat by myself during the lunch break [...] When I get home, I take a shower and wash the clothes I wore outside."

\subsection{Diversifying income sources and taking up loans}

To reduce their dependence on wages, some of the women interviewed tried to diversify their income sources. For example, Zhor, divorced, aged 40 and living with her sister and two children, became a housekeeper: "If a woman in Ain Touajdate [a town in the Saiss area] is looking for somebody to do the housework, I go to their home [...] If they [the authorities] stop me in the street, I tell them I am just going shopping." Others developed forms of mutual aid and solidarity. Rahma explained how she borrowed a neighbor's smartphone so that her daughter could take online courses. She shared the internet recharge costs with her neighbor, herself a mother with a child at school. Family members would also offer help. Half of the interviewed women indicated that they had benefited from family members' financial support. When there is no money left to buy food, they take loans from local shopkeepers. They would nevertheless try to reimburse their credit quickly, as Najat explained: "When my savings ran out, I took food on credit from the grocery store. Then I worked to pay off my debts."

\section{Discussion and conclusion}

"You know, here we are like the forgotten tombs. Nobody thinks about us." Souad, like the other women interviewed, "...felt forgotten". The experiences and plight of female agricultural wageworkers during the pandemic expose the "invisible" crisis that has unfolded in the Moroccan countryside, where the most vulnerable social categories have been hit the hardest (see also Ftouhi et al., 2021). Already in a precarious situation, these women faced new constraints. Reduced work opportunities and limited state support have led to financial and psychological hardship and jeopardized their own and their family's survival.

Their plight reveals two interrelated contradictions that are at the heart of today's Moroccan agricultural boom. Firstly, it shows how their productive work remains unrecognized and continues to be devalued. Although they are often the primary income provider or fundamentally supplement the other income sources of family members, their employers and the state treat them as secondary earners. Women struggled to benefit from state support, to obtain official work permits and moquefs, informal labor markets, were prohibited. As pointed out by Mies (1982), this process reduces the economic and political costs of production to a minimum and allows for the unrestricted maximization of profits (p. 200). Secondly, these women assume the primary responsibility of all the reproductive work, which continues to be activities that are not economically recognized or valued. With the necessity of continuing to fulfill their reproductive responsibilities, the women interviewed were forced to resume their work. They tried to find private solutions and developed strategies to survive. Some kept their heads up and did so with dignity, not being ready to accept just any work arrangement, as indicated by Zineb: "A farmer came to see me... but he offered $70 \mathrm{Dh}$ $( \pm 6.5 €)$. I told him that it was not enough and I asked him for $100 \mathrm{Dh}( \pm 9 €)$. He refused and said that he would give me $80 \mathrm{Dh}( \pm 7 €)$ but only to me and that I should not tell the other workers. I told him that I do not accept haram (sinful) money and that he should give us the same remuneration [...] I hate injustice." Yet, others had no remaining savings and did not know when they would have any work opportunities. Women who found themselves in such situations had less bargaining power over their wages, as in the case of Soundous: "It is better 
to work with a salary of 70 Dh than not working at all. If I don't work, no one will sustain me. Nobody will buy me a kilo of sugar."

These two interrelated contradictions translate to structurally precarious work situations: the great majority of female agricultural wageworkers work without contracts and do not benefit from social security. Such a situation is now boosting the growth of the agricultural sector, even in times of (partial) lockdown.

The women interviewed have a clear idea of how their situation could change and what support they need. Most aspire to higher wages to compensate for the drudgery of agricultural work. They also wish for a permanent and regular job so that they no longer have to worry daily about whether they will find work, as explained by Hafida: "I wish to have a job [...] I mean a permanent job. I want to get up in the morning and not ask myself, 'Is a farmer going to call me to work?". Others would like to become members of an association or cooperative in their village to share their experiences with other women and collectively meet their needs.

Finally, based on the challenges faced by the interviewed women, the two authors of this article also recommend to mobilize additional financial allowances to support reproductive activities, and vulnerable people could be assisted to apply for support correctly. Moreover, existing measures should consider new social realities and acknowledge the erosion of the "male breadwinner household" model, which hampers de facto female-headed households from benefitting from support.

Perhaps the time has come to bring fundamental changes and address the precariousness of female agricultural wageworkers in Morocco. The country has embarked on a new development model (Commission spéciale sur le modèle de développement, 2021 ) in which the local populations are at the heart of public policy priorities. They are the bearers and beneficiaries of this new development path. In addition, a new agricultural policy Generation Green (2020-2030) has been launched. Although nothing is mentioned about improving labor conditions for agricultural wageworkers, there is a strong emphasis on improving human conditions and reducing social disparities in the countryside. This greater attention to the human and social elements of development processes, combined with the generalization of social security for all Moroccans, one of the King's main calls in the wake of the pandemic crisis, testifies of an important political commitment. In this environment, it is crucial to revive the public debate around the precarious working conditions and reach out to the most vulnerable and hidden figures making the agricultural boom possible.

Acknowledgements. This paper has been significantly improved by critical comments provided by three anonymous reviewers. The research for this article was supported by Farming in times of crises: experiences, responses, and needs of smallholder farmers during the COVID-19 pandemic funded by DUPC2: IHE Delft Partnership Programme for Water and Development.

\section{References}

Bhattacharya T. 2017. Introduction: mapping social reproduction theory. In: Bhattacharya $\mathrm{T}$, ed. Social reproduction theory remapping class, recentering oppression. London (United Kingdom): Pluto Press, pp. 1-20. https://doi.org/10.2307/j.ctt1vz494j.5.

Bossenbroek L. 2019. Les ouvrières agricoles dans le Saïss au Maroc, actrices de changements sociaux ? Alternatives Rurales 7. http:// alternatives-rurales.org/les-ouvrieres-agricoles-dans-le-saiss-aumaroc-actrices-de-changements-sociaux/.

Bossenbroek L. 2016. Behind the veil of agricultural modernization: gendered dynamics of rural change in the Saiss, Morocco. Wageningen/Den Haag (The Netherlands): Wageningen University, $172 \mathrm{p}$.

Commission spéciale sur le modèle de développement. 2021. The New Development Model. [9/22/2021]. https://www.csmd.ma/ documents/Summary.pdf.

Fraser N. 2017. Crisis of care? On the social-reproductive contradictions of contemporary capitalism. In: Bhattacharya T, ed. Social reproduction theory remapping class, recentering oppression. London (United Kingdom): Pluto Press, pp. 21-36. https://doi. org/10.2307/j.ctt1vz494j.6.

Ftouhi H, Saidani MA, Bossenbroek L, Hamamouche MF, Kadiri Z. 2021. Entre vulnérabilité et résilience : le vécu de la pandémie de Covid-19 dans deux sociétés oasiennes du Maghreb. Cahiers Agricultures 30: 30. https://doi.org/10.1051/cagri/2021012.

Harbouze R, Pellissier JP, Rolland JP, Khechimi W. 2019. Rapport de synthèse sur l'agriculture au Maroc. Montpellier (France): CIHEAM-IAMM, 104 p. https://hal.archives-ouvertes.fr/hal02137637.

Joekes S. 1985. Working for lipstick? Male and female labour in the clothing industry in Morocco. In: Afsher H, ed. Women, work, and ideology in the Third World. London (United Kingdom): Tavistock Publications, pp. 183-213.

Laslett B, Brenner J. 1989. Gender and social reproduction: historical perspectives. Annual Review of Sociology 15: 381-404. https://doi. org/10.1146/annurev.so.15.080189.002121.

Mies M. 1982. The lace makers of Narsapur: Indian housewives produce for the World market. London (United Kingdom): Zed Press, $222 \mathrm{p}$.

Théroux-Séguin J. 2016. From empowerment to transformative leadership: intersectional analysis of women workers in the Strawberry Sector of Morocco. In Fletcher AJ, Kubik W, eds. Women in agriculture worldwide. Key issues and practical approaches. Oxon, New York (United States): Routledge, pp. 209-225.

Cite this article as: Bossenbroek L, Ftouhi H. 2021. The plight of female agricultural wageworkers in Morocco during the COVID-19 pandemic. Cah. Agric. 30: 40. 